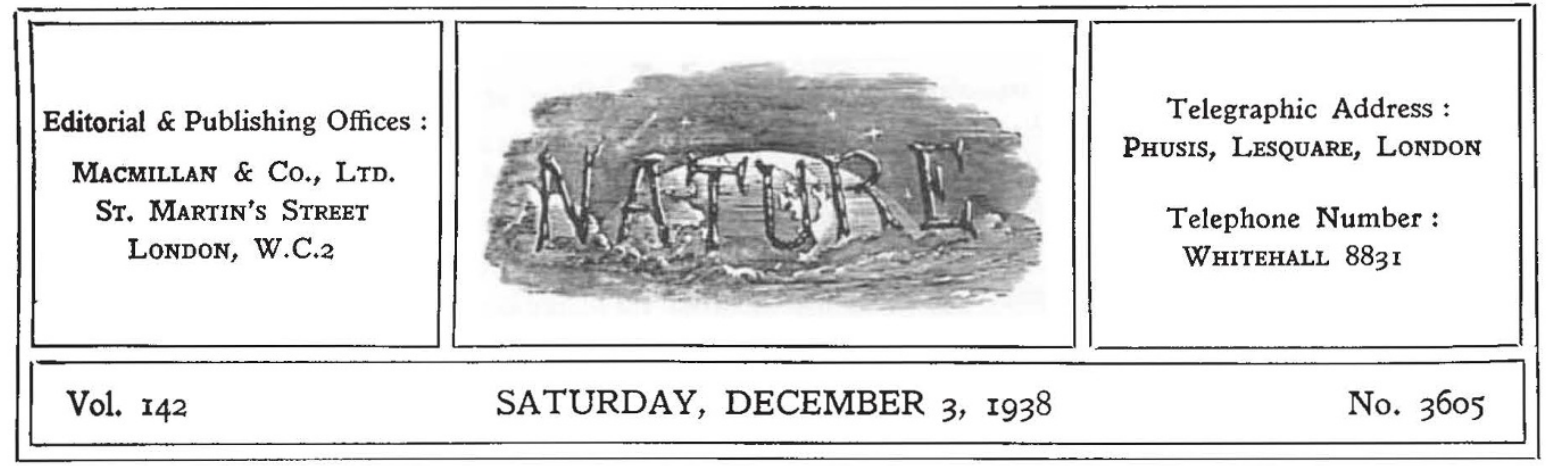

\title{
The Scientific Approach to Modern Life
}

$\mathrm{T}$ HE spirited address in defence of modern youth which Lord Tweedsmuir delivered on his installation as chancellor of the University of Edinburgh in July last has much to commend it to the attention of scientific workers. In describing the functions of a university, he added one more to the many voices warning us to-day that we must zealously defend the freedom and the integrity of our thought, boldly facing new conditions, ready to meet every problem, shirking no difficulty, but rigid in our fidelity to the laws which govern our intellectual being.

A university, Lord Tweedsmuir asserted, must transmit and advance knowledge. It is not only a seminary for the training of youth but also a museum for record, a laboratory for discovery and a power-house for inspiration. These duties are closely united, for without a centre of creative thought behind them, the professions for which the university trains youth will become stagnant and blind.

The maintenance of the delicate structure which we call civilization in the face of the destructive forces at work in the world to-day is a task to which the university must make an indispensable contribution. That task is not rendered the easier by any retreat to the older philosophies. Even if we can select one of the older systems as the basis of all learning, it is no simple matter to link it up with the multitudinous activities of the modern world, the study of the physical universe and of the infinite ramifications of human society. To select arbitrarily a set of first principles and to make all studies subordinate to them is in effect, as Lord Tweedsmuir pointed out, to establish an intellectual dictatorship and to kill the freedom $f$ the mind.
Significantly enough, Lord Tweedsmuir suggested that we should aim at giving our youth minds accustomed to think and inspired by a reverence for thought. At the same time, they must have the perspective created by some understanding of our long human story. Only thus can we endow them with what is most needed-confidence and hope. He went on to urge the claims of scientific research as a career, whether in the service of the universities, or industry, or of the State. Such a career, he said, offers a life of perpetual adventure, and in that field every university can do useful work.

There is indeed ample room for the spirit of adventure to-day and for the discipline behind it which makes adventure fruitful. Conceived in this way, scientific research offers a great opportunity, for it becomes linked to the development of personality, and the exploration and recognition of human values. The great and enduring human values inherent in our democratic institutions cannot be maintained by trying to stabilize the machinery through which they find expression. They can only be defended by being made to work effectively, and unless we can modify our institutions in line with the profound changes in the complexity and conditions of government, they may well perish.

Here, as Major L. Urwick suggested in a recent stimulating paper published in the British Management Review on "Administration and Society" is one of the challenges thrown down to modern youth : research into the human and social aspects of administration and government, which will yield the scientific knowledge by which we can bring mechanization under control and adjust accurately our social organization. The ideals and 
experiments outlined by E. Mayo in "Human Problems of an Industrial Civilization" (New York, The Macmillan Co., 1933) or T. N. Whitehead in "Leadership in a Free Society" (Oxford University Press), are only beginnings, but are pregnant with possibility.

It is indeed the neglect in the past of human purpose, psychological factors and social factors by industry that leads Gillespie in his recent book "The Principles of Rational Industrial Management" (London : Sir Isaac Pitman and Sons, Ltd., 1938) to reject the whole term 'scientific management'; for some of the protagonists and practitioners have undoubtedly been prone to overlook the limitations of science in management. Scientific method is only a tool of management. It is not the whole of management, and is not a substitute for personal values. Moreover, as Gillespie points out, not only has the social purpose of industry been neglected and its social responsibilities overlooked, but also management has often failed to recognize the significance of its own obedience to the purpose which industry is serving. It is a sound principle that one of the first steps in training for leadership is learning to obey, and management has often failed in obedience to its own rules and precepts, and to the full purpose which industry should serve.

Conceived on these lines, we need not fear that democratic institutions cannot be moulded by youth to meet the challenge of to-day. The problem of freedom, once more a cause to fight for, is encountered everywhere, no less in industrial than in national life. No less in the industrial unit than in the nation, the first condition of freedom is stability and a sense of justice, inspiring the loyalty which accepts not discipline so much as self-discipline and the co-operation and good will for free service in a common aim.

This is essentially the moral rearmament of which Sir William Bragg spoke in a recent broadcast address. Only the vision and inspiration of a great and noble purpose can suffice to rally youth to the task, not of service in the sense of defence only, but of building a new world order in which every individual and every community may find full opportunity for self-expression and development, and in which the national defences now being so hurriedly erected can be made unnecessary. This task demands much patient and painstaking research. It involves a wide vision and wise judgment in the direction of such research, and the reorientation of such effort, as well as the institution of research in fields yet largely untouched. It demands, too, the free acceptance of discipline and loyalty to the idea of service, and a capacity to evaluate all the issues, to see life steadily and to see it whole, which should appeal to all that is best in youth and command its steadfast allegiance and noblest endeavours no less than the daring and fortitude to which Lord Tweedsmuir paid tribute. Lord Tweedsmuir's address has earned the gratitude of all scientific workers, whether of the younger or of the older generations, no less for the clarity with which he has defined the challenge than for the inspiration with which it summons them to seize the opportunities which lie beyond that challenge.

\section{International Co-operation in Geology}

\section{Lexicon de Stratigraphie}

Vol. 1: Africa. Edited by Dr. S. H. Haughton. Pp. vi +432. (London: Thomas Murby and Co., 1938.) 31s. 6d. net.

\section{A} COMMISSION, elected at the fifteenth meeting of the International Geological Congress assembled at Pretoria in 1929, decided to produce a "Lexicon de Stratigraphie", with a volume devoted to each continent in turn. The general editorship was entrusted to Dr. S. H. Haughton, who has naturally started with Africa.

The purpose of each volume is to furnish definitions of all stratigraphical terms that have appeared in the geological literature of the particular continent, and to arrange them for convenience of reference in alphabetical order. The definitions must be accompanied by appropriate references and must indicate past and present meanings. Thus, in the case of a formation of local origin, the original meaning is cited along with the more significant of subsequent changes. Comments are added regarding geographical and geological relations; the whole, of course, in brief dictionary style.

In the present volume Dr. Haughton has been assisted by twenty-three collaborators, whose contributions are duly initialled. Most of them have written in English or French, a few in Italian. 